\title{
Erratum to: Re-evaluating the Neolithic: The Impact and the Consolidation of Farming Practices in the Cantabrian Region (Northern Spain)
}

Miriam Cubas ${ }^{1} \cdot$ Jesús Altuna $^{2}$ Esteban Álvarez-Fernández ${ }^{3}$.

Angel Armendariz ${ }^{4}$ Miguel Ángel Fano ${ }^{5}$ Inés L. López-Dóriga ${ }^{4}$.

Koro Mariezkurrena ${ }^{2} \cdot$ Jesús Tapia $^{6} \cdot$ Luis C. Teira $^{4} \cdot$

Pablo Arias ${ }^{4}$

Published online: 20 May 2016

(C) Springer Science+Business Media New York 2016

\section{Erratum to: J World Prehist (2016) 29:79-116 DOI 10.1007/s10963-016-9091-2}

The original version of this article unfortunately contained an authorial error in the "Introduction" section; the phrase fifth millennium should read sixth millennium, so the text should read:

The online version of the original article can be found under doi:10.1007/s10963-016-9091-2.

\author{
Miriam Cubas \\ miriam.cubas@york.ac.uk \\ Jesús Altuna \\ altuna@arkaios.com \\ Esteban Álvarez-Fernández \\ epanik@usal.es \\ Angel Armendariz \\ angel.armendariz@unican.es \\ Miguel Ángel Fano \\ miguel-angel.fano@unirioja.es \\ Inés L. López-Dóriga \\ i.lopezdoriga@wessexarch.co.uk \\ Koro Mariezkurrena \\ altuna@arkaios.com \\ Jesús Tapia \\ jtapia@aranzadi-zientziak.org \\ Luis C. Teira \\ luis.teira@unican.es \\ Pablo Arias \\ pablo.arias@unican.es
}


The introduction of agriculture in Andalusia and Catalonia is dated around the mid sixth millennium cal BC (Peña-Chocarro and Zapata 2012), as in the Central Plateau (the Meseta) (for example, La Lámpara or La Revilla, Rojo et al. 2008).

1 BioArCh, University of York, Environment Building, Wentworth Way, Heslington, York YO10 5NG, UK

2 Arkaios Investigaciones, Mendigain 30, 20014 San Sebastián, Spain

3 Departamento de Prehistoria, Historia Antigua y Arqueología, Facultad de Geografía e Historia, Universidad de Salamanca, c/Cerrada de Serranos s/n, 37002 Salamanca, Spain

4 Wessex Archaeology, Portway House, Old Sarum Park, Salisbury SP4 6EB, UK

5 Departamento de Ciencias Humanas, Universidad de La Rioja, Edificio Vives C/Luis de Ulloa, s/n, 26004 Logroño, Spain

6 Sociedad de Ciencias Aranzadi, Zorroagagaina 11, 20014 Donostia-San Sebastian, Spain 